\title{
DAMPAK KAPITULASI TERHADAP PERADILAN TURKI UTSMANI
}

\author{
Asa'ari \\ Institut Agama Islam Negeri (IAIN) Kerinci \\ email: asy.husein@gmail.com
}

\begin{abstract}
The Ottoman Empire stood above Sharia's Islam, which at first was only a sultanate and then its power expanded to the gates of Vienna (Austria), the North African region, Arabia and its territory to Aceh Darussalam. The Legal Capitulation Treaty was favorable in the heyday, because traders were stimulated to carry out activities in the Ottoman ports, especially in Istanbul. Significant increase in the country's foreign exchange, so that large activities are carried out without any monetary shock. After a leadership crisis, this legal capitulation agreement has been fruifful. More and more foreign consuls, expanded treaties and sharia judgments began to lose function because many Christian citizens and Jews who had never known the French, British and other European countries had taken refuge behind the Capitulation agreement which had privileges in tax relief, immune from civil or criminal law. This led to the secularism of Ottoman law which contained European law material. There is an uncontrolled Tanzimat, it should only be in the field of military and economic technology and strategy but has penetrated the judicial system and legal material. Which ends with the loss of Ottoman sovereignty.
\end{abstract}

Keyword: : Capitulation, Justice, Ottoman Turkey

\begin{abstract}
Abstrak: Turki Utsmani berdiri diatas Syari'ah Islam, yang pada mulanya hanya sebuah kesultanan kemudian kekuasaannya berkembang sampai ke pintu gerbang kota Wina (Austria), wilayah Utara Afrika, Arab dan teritorinya sampai ke Aceh Darssalam. Perjanjian Kapitulasi Hukum yang menguntungkan pada masa jaya, karena para pedagang dirangsang untuk melakukan aktifitas dipelabuhan-pelabuhan Turki Utsmani terutama di Istanbul. Penambahan devisa negara secara signifikan, sehingga aktifitas-aktifitas besar dilakukan tanpa ada kegoncangan moneter. Setelah terjadi krisis kepemimpinan, perjanjian kapitulasi hukum ini berbuah menjadi malapetaka. Konsul-konsul asing semakin banyak, perjanjian diperluas dan peradilan-peradilan syari'at mulai kehilangan fungsi karena banyak warga negara Nasrani dan Yahudi yang tidak pernah mengenal negara Perancis, Inggris dan Eropa lainnya telah berlindung dibalik perjanjian Kapitulasi yang mendapatkan hak istimewa dalam keringanan pajak, kebal hukum perdata maupun Pidana. Hal ini berujung kepada sekularisme Hukum Turki Utsmani yang memuat materi-materi Hukum Eropa. Terjadilah Tanzimat yang tidak terkontrol, seharusnya hanya di bidang teknologi dan strategi militer dan ekonomi akan tetapi telah merambah kepada sistim peradilan dan materi hukum. Yang berakhir dengan hilangnya kedaulatan Turki Utsmani.
\end{abstract}

Kata Kunci: Kapitalis, Peradilan, Turki Utsmani 


\section{PENDAHULUAN}

Kesultanan Turki Utsmani yang sejak berdirinya (1299) dibawah pimpinan Osman Bey, adalah berdiri kokoh diatas Syari'at Islam, namun pada periode berikutnya mulai bergeser ke hukum sekuler. Ini terjadi pada akhir abad-19, tepatnya pada era Tanzimat (1839-1876), sehingga menjadi sebuah tanda tanya besar, karena pada dasarnya perubahan ini tidak mungkin muncul dengan tiba-tiba. Faktor apakah yang membuat sebuah emperium besar yang tadinya tegak berdiri dengan penuh wibawa merubah hukum yang ada di negaranya ? Era tanżimat merupakan gerakan pembaharuan yang terjadi di Turki Utsmani, yang pada hakikatnya berintikan upaya pemerintah Turki Utsmani untuk melakukan perbaikan dalam tata aturan perundangan di segala bidang, dan salah satu kodifikasi hukum yang disusun adalah Majallah al-Abkam al-Adliyah (1876 M), di samping piagam Gulbane dan Humayun.

Negara Turki Utsmani, adalah sebuah negara multi-etnis yang beberapa abad mendominasi keseimbangan kekuatan militer, politik dan hukum di Eropa. Turki Utsmani telah menjadi lambang sebuah kekuatan dan supremasi hukum di dunia Islam dan di Eropa; banyak peristiwa dan perjanjian-perjanjian yang dilakukan serta penyusunan hukum bilateral dengan Perancis maupun multilateral dengan Rusia, Inggris, dan negara-negara Eropa Barat. Negara ini lebih dekat kepada sebutan imperium, karena ia telah menggantikan kedudukan dua kerajaan sekaligus yaitu kerajaan Persia dan Romawi Timur (Byzantium) dan Romawi Barat.

Wilayah Hukumnya meliputi hampir seluruh negera Arab kecuali Maroko, Azarbaijan, Cremia, Kaukasus, Armenia, Serbia/Bosnia, Bulgaria, Romania serta Yunani. Dan pada masa Sultan Salim, Aceh Darussalam merupakan bagian dari Turki Utsmani. Semuanya telah berada dibawa kontrol hukum Islam, yang akhirnya naik tahtalah seorang Sulltan. Sultan yang kuat dan bengis yang bernama Sultan Salim. Di Inggris ia dikenal sebagai Selim the Grim (yang selalu cemberut). Ia ingin memaksa seluruh penduduk serta etnis yang ada di bawah Turki Utsmani untuk beragama Islam dan menggunakan Bahasa Arab sebagai bahasa resmi negara, termasuk penduduk Eropa Timur, akan tetapi hal ini ditentang oleh ulama, yang akhirnya Sultan tunduk kepada keputusan ulama. Artinya, Sultan juga tidak berkuasa mutlak dalam membuat keputusan, ia harus merujuk kepada hukum syara' sebagai undang-undang dasar yang tertera dalam al-Qur'an dan Hadits; apabila tidak tertera di dalam keduanya maka akan digali tafsir dannhukumnya oleh para ulama. (الأندلس وشمال الافريقية, مححد أمين, بيروت 1992 ص.23 )

Peradilan pada masa Turki Utsmani murni bersandarkan pada Syari'at Islam sesuai dengan mazhab Hanafi. Sedangkan hukum jinayat dan hukum yang lain diterapkan di negara 
ini secara baku setelah masa Tanzimat. Sebelumnya hanya berdasarkan fatwa ulama dan syaikh al-Islam. Penerapan hukum ini telah dicanangkan dalam kitab al-Ahkam al-'Adliyah yang berhubungan dengan bab peradilan, kesaksian, pengakuan, sumpah, perdamaian, wikalah dan ketetapan-ketetapan hukum lainnya. Segala proses dan berita acara pengadilan dicatat dalam sebuah buku, dari buku-buku tersebut dapat dianalisa sumber peradilan, dan catatan legitimasi peradilandan hukum yang berlaku pada masa Turki Utsmani.

Mayoritas masyarakat Turki Utsmani menganut mazhab Hanafi walaupun terdapat penganut mazhab-mazhab lain yang terkemuka dalam mazhab-mazhab Islam seperti mazhab Syafi'i, Hanbali dan Maliki. Oleh karena itu dipercayakan pada hakim untuk mengambil keputusan peradilan sesuai dengan mazhab Hanafi. Kadangkala keputusan pengadilan juga merujuk kepada mazhab-mazhab lain. Atau faqih tertentu yang sanggup melakukan ijtihad baru tentang permasalahan yang dihadapi dengan izin Sultan. Fatwa, dengan demikian menjadi salah satu sumber tasyri' pula di masa itu.

Namun fondasi hukum Islam yang kokoh di Kesultanan Turki Utsmani ini, secara perlahan melemah, dan akhirnya tergususr oleh hukum sekuler. Kapitulasi benar-benar telah menjadi gerbang kehancuran tatanan hukum, ekonomi, social dan budaya bagi Ottoman.

Dengan tulisan ini akan dilihat bagaimanakah bentuk kapitulasi asing yang diberlakukan pada masa Turki Utsmani, sejauh mana andil kapilulasi asing dalam perubahan struktur dan materi hukum dalam peradilan Turki Utsmani, dan apa saja dampak kapitulasi asing terhadap peradilan Turki Utsmani dan kedaulatan imperium ini di wilayah taklukannya seperti Mesir, Syria, termasuk Aceh Darusalam (Nusantara).

\section{METODE}

Penelitian ini masuk kategori penelitian kepustakaan (library research) yang sifatnya kualitatif; menekankan pada pembacaan perubahan sistem, struktur, dan materi hukum di Turki Utsmani, serta kajian dan analisis terhadap dampak kapitulasi asing yang terjadi. Kajian dialakukan dengan histirical aproach (pendekatan sejarah), dan sosiologi hukum Islam.

Data-data dikumpulkan melalui teknik penelitian kualitatif, yakni teknik penelitian yang berlandaskan filsafat postpositivisme, digunakan untuk meneliti pada kondisi objek yang alamiah (naturalistic) di mana peneliti adalah sebagai istrumen kunci, teknik pengumpulan data 
dengan trianggulasi (gabungan), analisis data bersifat induktif dan hasil penelitiannya lebih menekankan makna daripada generalisasi. ${ }^{1}$

Sumber utama data adalah dokumen-dokumen sejarah terkait objek matter penelitian, dianalisis dengan langkah-langkah editing, reduction, coding, dan meaning untuk kemudian masuk ke tahap konklusi.

\section{HASIL PENELITIAN DAN PEMBAHASAN}

\section{Dampak Kapitulasi Terhadap Peradilan Turki Utsmani}

Hasil dari hukum impor adalah munculnya dualisme sistim peradilan dan pengadilan dalam Daulah Utsmaniyah. Hal ini terjadi akibat persekongkolan Barat terhadap Daulah Utsmaniyah yang sudah mulai rapuh diterpa krisis kepemimpinan, degradasi keimanan, yang berunjung kepada penyimpangan penerapan syari'at Islam, sehingga rasa waspada dan kepekaan terhadap bahaya yang akan datang telah dikikis oleh sikap hedonis para pemimpin negara yang selalu berada diatas menara gading. Akan tetapi hal tersebut belum lagi cukup bagi dunia Barat; tetapi mereka akhirnya menyelesaikannya dengan peperangan yang tiada henti. Ditambah lagi dengan kapitulasi yang selalu dijadikan alat untuk melakukan eksploitasi terhadap ekonomi yang berdampak kepada peradilan dan keadilan. Walaupun perbaikan-demi perbaikan dilakukan dalam bidang hukum dan peradilan tetapi tidak juga berhasil karena selalu mendapat halangan dan rintangan.

Penyakit dualisme peradilan ini terus berlanjut, para negarawan meninggalkan penerapan hukum Islam yang telah membawa Daulah Utsmaniyah kepada kejayaan masa lalu dengan menggantinya dengan peradaban Barat. Negara-negara Barat terus melakukan penekanan dengan cara-cara penjajahan. Mereka melakukan campur tangan dalam urusan pemerintahan Daulah Utsmaniyah. Sultan Abdul Majid terpaksa mengeluarkan Firman tentang Reformasi yaitu dengan terbitnya piagam Gulhane pada tahun 1839 M/1255 H. Kemudian muncul lagi perjanjian Khat Hamayun pada tahun 1856 M/1274 H. Setelah itu didirikanlah pengadilan sekular di berbagai wilayah. Seperti pengadilan magistrate, pengadilan percobaan, pengadilan banding, pengadilan pidana dan tipikor, pengadilan kasasi, pengadilan tata usaha negara, pengadilan kelompok minoritas, pengadilan asing (pengadilan consulate) yang berada dibawah kedutaan-kedutaan asing yang khusus menangani warga asing dan dianggap warga asing sebagai konsekuensi dari perjanjian kapitulasi. ${ }^{2}$

\footnotetext{
${ }^{1}$ Sugiyono. 2011. Metode Penelitian Kuantitatif, Kualitatif dan R\&D. Bandung: Afabeta
}

2 Muhammad Zuhaili, Tarikh al-Qadha fi al-Islam, Beirut, Dar al-Fikr, 1992. 
Setelah itu pengadilan-pengadilan ini melepaskan diri dari pengadilan syariah dan menerapkan hukum-hukum impor dari Eropa yang sebenarnya tidak lagi dipakai di Eropa Modern, termasuk hukum-hukum yang berlaku di Swiss pada abad pertengahan.

1. Pengadilan Reguler

Pendirian pengadilan regular merupakan titik perubahan sistim peradilan Syar'i dalam mendominasi peradilan di kekaisaran Ottoman. Dualisme terjadi karena telah ada dua sistim peradilan yaitu Peradilan Islam dan Peradilan Reguler. Piagam Hamayuni diterbitkan untuk memelihara hak-hak minoritas, penghapusan hukuman mati hasil adopsi sistim peradilan dan undang-undang asing (Abdurrazak Sanhuri)

Pengadilan Reguler terlepas dari peradilan syara', yang mana pengadilan syara' dijadikan rujukan sementara. Setelah para hakim pengadilan regular dapat bekerja dengan baik pada waktu itulah pengadilan agama mengerucut dan hanya menangani permasalahan ahwal al-syakhsiyah (kawin, talak, ruju' dan waris). ${ }^{3}$ Pengadilan Reguler terdiri dari: ${ }^{4}$

a. Pengadilan Magistrate: didirikan pada tahun 1913 M/ 1329 H, pengadilan ini adalah pengadilan bergerak (mobile) yang berpindah-pindah dari desa ke desa. Mahkamah ini mempunyai satu hakim apabilah hakim tidak ada maka perkara akan diselesaikan oleh wakilnya. $^{5}$

b. Pengadilan Tingkat Pertama, pengadilan ini terdapat di pusat peradilan. Terdapat di beberapa wilayah yang dilaksanakan oleh satu orang hakim kepala dan empat orang anggotanya.

c. Pengadilan Perdagangan, pengadilan ini didirikan pada tahun 1277 H, 1860 M, terdiri dari hakim ketua dan dua anggota tetap dan empat anggota tidak tetap. ${ }^{6}$

d. Pengadilan Banding: pengadilan ini ada berdomisili di ibukota propinsi yang mempunyai wewenang dalam perkara sipil, keuangan, tindak pidana. Pengadilan ini terdiri dari lima orang hakim, seorang ketua, empat orang anggota. Dua dari hakim tersebut seorang muslim dan dua dari non muslim. Keanggotaannya berlangsung selama dua tahun dan pengadilan banding ini adalah pengadilan paling tinggi kedudukannya diantara pengadilan tingkat pertama. ${ }^{7}$

e. Pengadilan Kasasi: Pengadilan ini ada di Istanbul, pusat pemeritahan Daulah Utsmaniyah

${ }^{3}$ Bazin, Louis, La Vie Intellectuelle et Culturelle dans Empire Ottoman,en Histoire de /'Empire ottoman, Paris, Fayare, 1989.

${ }^{4}$ Muhammad Az-Zuhaili, Tarikh Al-Qadha fi Al Islam, Dar Al Fikr, Cet. II, Damaskus, 1422H/2001 M.

${ }^{5}$ Bittar,T., Soliman. L'empire magnifique, Paris, Gallimard Découvertes, 1994

${ }^{6}$ Muhammad Az-Zuhaili, Op., Cit.

${ }^{7}$ Muhammad Az-Zuhaili, Ibid. 
f. Pengadilan khusus: Pengadilan ini adalah pengadilan istimewa yang didirikan setelah perjanjian kapitulasi. Pengadilan ini ada dua jenis: ${ }^{8}$

1) Pengadilan Konsulat, pengadilan ini didirikan oleh konsulat asing untuk memutuskan perkara warganya yang ada di wilayah Turki Utsmani. Seluruh hakimnya terdiri dari orang-orang asing yang terkait dengan perjanjian kapitulasi tersebut.

2) Pengadilan Spiritual, pengadilan ini menangani masalah kelompok agama minoritas non muslim yang menyelesaikan perkara hukum keluarga yang terkait dengan kelompok minoritas. Kedua pengadilan diatas yaitu pengadilan Konsulat dan pengadilan Spritual diperbolehkan karena Daulah Utsmaniyah menganut mazhab Hanafi sedangan jumhur fuqaha hakim dalam komonitas muslim atau negara Islam haruslah seorang muslim, termasuk hakim yang bertindak dalam penyelesaian perkara non muslim haruslah seorang muslim. Hal ini disebabkan perkara tersebut diselesaikan di wilayah mayoritas muslim dan di negara Islam yang mempunyai otoritas terhadap masyarakat non muslim dalam peradilan dan hukum.

2. Pengadilan Syari'ah

Mahkamah Syari'ah merupakan lembaga dasar peradilan negara Ottoman, akan tetapi kewenangannya mulai dibatasi setelah timbulnya kapitulasi hukum yang diadakan pada masa Muhammad al-Fatih dan Sulaiman al-Qanuni, ditambah lagi dengan masa Sultan Murad III. Mahkamah Syari'ah akhirnya hanya mengurusi perkawinan, perceraian dan warisan dengan kata lain hanya sebatas Ahwal al-Syakhsiyah saja. Permasalahan jinayat, qisas dan ta'zir tidak lagi urusan Mahkamah Syari'ah dan telah beralih kepada pengadilan reguler.

Selain itu didirikan juga Pengadilan Kasasi Khusus. Pengadilan ini didirikan oleh Napoleon ketika menduduki Mesir, ia membuat sebuah lembaga dan menamakannya Pengadilan Kasasi Khusus, yang terdiri hakim ketua yang berasal dari etnis Koptik (penduduk Mesir asli). ${ }^{9}$ Sedangkan anggotanya separoh muslim dan separoh lagi Koptik. Fungsi pengadilan ini adalah menyelesaikan perkara perdagangan dan permasalahan umum. Napoleon mengangkat hakim agung yang berasal dari putra daerah atau pemuka masyarakat dan bukan dari hakim yang tadinya diutus oleh Daulah Utsmaniyah. Setiap pihak yang berperkara membayar ongkos perkara 50\% dari nilai komoditi yang diperkarkan. Biaya tersebut dibagikan kepada para hakim dan paniteranya. Setelah itu

${ }^{8}$ Muhammad Az-Zuhaili, Ibid.

${ }_{9}$ Muhammad Az-Zuhaili, Ibid. 
dibangunlah lembaga peradilan independen yang terlepas dari wilayah hukum Daulah Utsmaniyah, akan tetapi tidak ada yang baru dan sebagian besar hanya mencontoh peradian yang terdahulu. ${ }^{10}$

Untuk memuluskan kapitulasi, dan memudahkan hakim-hakim umum yang tidak paham hokum syari'ah maka disusunlah suatu kitab yang disebut Al-Majallat aAl-Ahkam Al-'Adliyyah.

Majallah ini adalah Undang-Undang Mu'amalah Keuangan dan Perdata yang berasal dari Mazhab Hanafi. Undang-undang ini dikodifikasikan karena timbulnya peradilan regular yang sekuler, akan tetapi lebih sistimatis, adopsi dari sistim peradilan Barat. Walaupun begitu pengadilan ini tidak dapat berdiri sendiri, pengadilan ini sangat membutuhkan bimbingan pengadilan syari'ah sampai dapat beroperasi dengan baik selama bertahun tahun. Hakim-hakimnya terdiri dari hakim-hakim umum yang belum berpengalaman. Peradilan menjadi tidak efisien karena hakim-hakim syariah harus melakukan pencerahan kepada hakim-hakim umum ini. Untuk memudahkan hakim-hakim sekuler ini memutuskan perkara disusunlah majallah al-Ahkam al-Adliyah pada thaun 1286 H/1869 M. Penyusunan ini berdasarkan pendapat-pendapat yang kuat dari mazhab Hanafi dan pendapat yang lemah apabila itu mengandung maslahat bagi negara yang disesuaikan dengan perkembangan zaman dan tempat hukum itu diterapkan. Hukum-hukum mazhab Hanafi ini disusun sesuai degnan aturan perundang-undangan Barat agar mudah dijadikan rujukan. Pada taun 1851 disempurnakanlah majallah ahkam adliyah ini dengan pasal dan ayatnya beserta penjelasannya yang berjudul "Laihah al-Asbab al-Mujibah" yang dijadikan sebagai catatan penjelasan Majjalah al-Ahkam al-Adliyah tersebut. Ia mempunyai dua pendahuluan tentang definisi fiqh dan pembagiannya dan tentang qawaid fiqh yang terdiri dari 99 pasal. (Muhamad al-Zuhayli : 1415/1995)

\section{Dampak Kapitulai Terbadap Pengadilan di Teritorial Utsmani (Mesir, Al-Jazair, Suriah dan Iraq)}

1. Infiltrasi undang-undang asing ke Mesir dimulai pada tahun 1840, tahun di mana kelompok anti kolonianlis Barat mengadakan perjanjian antara Muhammad Ali dan Daulah Utsmaniyah. Eropa ini menghancurkan Mohammed Ali dan kekuatan Kekaisaran Ottoman yang saling berperang dan tentara mereka dengan melempar satu batu untuk dua burung dengan kata lain sambil menyelam minum air. Negara-negara Eropa campur tangan secara kolektif dengan melakukan rekonsiliasi antara kedua pihak untuk mencapai mereka

${ }^{10}$ Muhammad Az-Zuhaili, Ibid. 
mengurangi pengaruh Muhammad Ali dan dominasi khalifah, telah mencapai kehancuran kekuatan militer kekhalifahan, Eropa memutuskan untuk mempertahankan khalifah yang hampir mati dan tidak memungkinkan munculnya kekhalifahan baru di bawah kekuasaan Muhammad Ali diperbaharui Pemuda dari dunia Islam. Lalu Pada tahun 1840 kekhalifahan itu melemahkan oleh perang dengan Muhammad Ali telah menandatangani praktisi di bawah pengaruh Eropa, Eropa mampu memaksakan pengaruhnya terhadap suksesi dan Muhammad Ali bersama-sama. Eropa campur tangan tentara tepat waktu setelah pasukan kelelahan Alpartyan memaksa armada Muhammad Ali untuk mundur dan melakukan penandatanganan Konvensi London 1840, dan kerentanan Muhammad Ali sehingga ia harus membuka pasar Mesir terbuka lebar untuk perdagangan Eropa dalam pelaksanaan perjanjian menyimpulkan sebelumnya, Mesir menjadi surga bagi petualang dan rentenir dan lain-lain di bawah Nuansa sistem konsesi asing. Setelah itu, Muhammad Ali mendirikan pada tahun 1840 sebuah pengadilan istimewa yang khusus menangani permasalahan perdagangan yang mana orang asing banyak terlibat di dalamya yang disebut dewan pedagang "papan dari ketentuan Trade", yaitu sekitar pengadilan komersial untuk mengadili sengketa komersial antara antara para pedagang lokal dan Perancis, dan terdiri dari pengadilan ini dari Kepala pengadilan dan panitera, notulen, dan para pedagang yang dipilih oleh pengadilan untuk sebagai anggota tetap, lima dari mereka nasionalis dan tiga orang asing, baik Kairo maupun Alexandria memiliki pengadilan jenis ini. Dan representasi dari pedagang asing di pengadilan, pintu telah dibuka dalam praktek undang-undang asing untuk menyusup ke Mesir, dan terus mereka pengadilan beroperasi sampai masa pemerintahan Ismail, dan ditambabkan ke pengadilan banding disebut "Appeal Board", karena jumlab orang asing meningkat menjadi sama dengan jumlah nasional dan pengadilan ini dihapuskan Digantikan oleh pengadilan campuran pada tabun $1876 .^{11}$

2. Kolonialisme dan murid-muridnya mengatakan bahwa "hukum dan sistim perundangundangan asing telah menggantikan legislasi Islam karena stagnasi undang-undang Islam dan ketidaksesuaiannya pada pembangunan, dan bahwa kolonialisme tidak ingin campur tangan, para kolonialis hanya menginginkan pengembangan alamiah bertanggung jawab untuk itu."

3. Jika dokumentasi sejarah membuktikan mereka yang mengatakan bahwa undang-undang asing telah menggantikan undang-undang Islam karena kekakuan undang-undang Islam dan kurangnya pengembangan, studi lebih lanjut membuktikan bahwa ini adalah sesuatu yang

11 Stewart, Devin J, Note on Medieval and Modern Emendations of The Qur'an, dalam Gabriel Said Reynold (ed), The Qur'an in its Hostorical Context. USA: Routledge, 2008. 
disengaja dan sudah direncanakan dari kalangan kolonial, pada tahun 1908 dicetak partai reformasi konstitusi diterjemahkan sebuah buku berjudul "huruf Mesir politikus Inggris yang besar pada tahun 1905 termasuk buku empat belas pesan: oleh Inggris Mesir dan ditemukan di anggota liberal parlemen Inggris meninggalkan" Sir Robertson, bahwa sistem legislatif peradilan baru berasal dari Mesir tiba-tiba dalam satu hari Dan salah Kairo dan di tangan bangsa asing dan membuat rezimnya pada pola sistem filial dari peradilan Barat. Penerapan hukum Barat tidak bisa diterapkan dengan mudah karena hukum tersebut tidak muncul dari Mesir atau wilayah yang ada disekitarnya. Sehingga hukum tersebut menghilangkan manfaat karena tidak sesuai dengan kecenderungan rakyat, adat istiadat dan ritual keagamaan dan tradisi, dan hak .Kompleksitas tujuan dari pengaruh buruk asing dan ukuran yang sesuai, telah rusak dan menyimpang tradisi negara ini.

4. Selain mereka pengadilan, atau pedagang dewan, hak istimewa asing dinikmati oleh warga negara asing pada umumnya dan Eropa khususnya yang pintu lebar lain untuk infiltrasi undang-undang asing untuk negara kita, dan kisah waralaba asing adalah bahwa Kekaisaran Ottoman Pada guna membentengi umat Islam di negara itu terhadap pengaruh Alojunbaadalah orang asing telah dilarang dari hak untuk memiliki real estate di tanah kekuasaan Ottoman, kemudian ia kembali di bawah tekanan Eropa .

\section{Tanzimat dan Penghapusan Kapitulasi Hukum yang Terlambat}

Pada paruh akhir abad ke-18, Renaisans, revolusi militer, dan penemuan Dunia Baru semuanya dikombinasikan untuk memberi Eropa Barat keunggulan militer dan komersial yang berbeda atas Kekaisaran Ottoman. Baru pada akhir abad ke-18, bagaimanapun, bahwa Ottoman sepenuhnya menyadari gravitasi dari tantangan yang dihadapi mereka. Invasi Napoleon ke Mesir pada 1798 benar-benar menghancurkan ilusi kekebalan Utsmani. Sebelum acara ini, kemajuan militer Eropa ke dunia Islam sebagian besar terbatas di perbatasan utara Kekaisaran Ottoman; Austria dan Rusia terus maju ke Balkan dan di sepanjang pantai timur Laut Hitam. Peningkatan kekuatan komersial dan industri di Eropa, dan khususnya, Inggris, pada akhirnya menyebabkan dominasi hampir total perdagangan Ottoman oleh kekuatan Eropa. Sampai awal abad kesembilan belas, Daulauh Utsmaniyah masih percaya itu bisa memodifikasi kapitulasi untuk mencegah pelanggaran berat; pada tahun 1809, misalnya, Inggris menerima bahwa konsulnya telah menyalahgunakan sistem yang berat. ${ }^{12}$

12 Wood, Leonard G. H, Islamic Legal Revival: Reception of European Law and Transformations in Islamic Legal Thought in Egypt, 1875-1952, Oxford University Press, 2016. 
Reformasi sistem kapitulasi memucat dalam arti penting untuk memadamkan krisis internal yang menimpa Kekaisaran Ottoman sepanjang kuartal pertama abad kesembilan belas; kebangkitan Mehmed Ali Pasha dan pemberontakan Yunani menjadi contoh yang paling mencolok. Kenyataannya, ketika para birokrat Ottoman mulai melihat reformasi gaya Barat sebagai kunci untuk melestarikan kemerdekaan dan integritas kekaisaran, upaya yang dirancang untuk membatasi integrasi ekonomi Ottoman ke dalam pasar Eropa yang semakin meluas ditinggalkan. Dalam mengingkari hak istimewa yang telah diberikan Selim III kepada pedagang pribumi, Mahmud II (memerintah 1808-1839) membuat semuanya tidak mungkin bagi mereka untuk bersaing dengan orang Eropa.

Dilihat dari sudut ini, penandatanganan Konvensi Perdagangan Anglo-Turki tahun 1838 di Balta Liman boleh dibilang menjadi kesimpulan logis bagi kebijakan Ottoman selama sepuluh hingga lima belas tahun sebelumnya dan bukan hanya harga yang harus dibayar untuk bantuan Inggris dalam menghentikan penyegaran Mesir Mehmed Ali Pasha. Apa pun asalusulnya, hasil dari Konvensi itu tidak salah lagi.

Pada paruh kedua abad kesembilan belas, sistem kapitulasi telah dilihat sebagai simbol inferioritas Ottoman vis-a-vis Eropa. Sedangkan kapitulasi awalnya diberikan kepada Kekuatan Besar Eropa, antara tahun 1838 dan 1856 negara-negara kecil seperti Sardinia, Swedia, Spanyol, Portugal, Belanda, Belgia, Denmark, Tuscany, Kota Hanseatic, Yunani, dua Sicilia, Prusia, dan penandatangan lain dari Zollverein semua menandatangani perjanjian serupa. Ottoman juga menandatangani perjanjian komersial dengan negara-negara non-Eropa; Amerika Serikat pada tahun 1830, Brasil pada tahun 1858, dan Meksiko pada tahun 1864.

Sepanjang era Tanzimat, yang mengacu pada upaya reorganisasi administratif Kekaisaran Ottoman antara 1839 dan 1876, negarawan Utsmaniyah percaya bahwa selama kekuatan Eropa menghormati kedaulatan negara mereka ada sedikit atau tidak ada bahaya dalam memungkinkan orang Eropa mendapatkan akses yang lebih besar ke negara mereka. ekonomi. Pada tahun 1869, dalam upaya lain untuk mengekang penjualan berats, Daulauh Utsmaniyah memberikan kewarganegaraan kepada semua mata pelajaran Ottoman sehingga membuatnya tidak diperlukan dan bahkan ilegal bagi orang-orang untuk mencari atau menerima perlindungan kekuatan asing. Kedutaan asing dan mayoritas besar mata pelajaran Utsmaniyah, yang terus mengidentifikasi dengan komunitas agama mereka (millet) dan bukan negara, mengabaikan hukum baru.

Ketidakpedulian yang ditunjukkan oleh kekuatan Eropa terhadap upaya Ottoman untuk membatasi pengaruh mereka akhirnya memberi jalan untuk penghinaan terang-terangan 
sebagai Darwinisme sosial dan aspek lain dari imperialisme pertengahan hingga akhir abad kesembilan belas menyebabkan orang Eropa untuk melihat Turki sebagai korup dan rasial dan secara moral lebih rendah. Janji para reformis bahwa westernisasi pada akhirnya akan menyebabkan paritas dengan Eropa berdering semakin hampa saat era Tanzimat hampir berakhir. Dimulai pada 1860-an, strata sosial yang paling terpengaruh oleh westernisasi menjadi semakin kritis terhadap reformasi (lebih lanjut). Pemberontakan Balkan tahun 1875 dan kekalahan Ottoman dalam Perang Rusia-Turki 1877-1878 hanya memperkuat posisi yang disebut Ottoman Muda.

Itu tidak sampai Abdulhamid II datang ke tahta pada 1876 bahwa Turki Utsmani berpaling dari ketergantungan hampir total pada Inggris. Beralih ke Imperial Jerman, bagaimanapun, menawarkan sedikit manfaat praktis. Kaiser setuju untuk menghapus kapitulasi tetapi hanya jika kekuatan besar lainnya juga melakukannya. Penembusan Barat dari Kekaisaran Ottoman meningkat selama abad kesembilan belas. Konsul sedang dikirim di seluruh tanah Ottoman untuk membela kepentingan komersial dan hukum pedagang Eropa dan meningkatnya jumlah misionaris. Penyebaran orang-orang yang diberkahi dengan kekuatan kapitulasi secara signifikan menggerogoti struktur pemerintahan Ottoman. Pada awal abad ke-20, misalnya, seorang polisi Ottoman bahkan tidak dapat memasuki rumah seorang warga negara asing tanpa izin dari konsul / kedutaan yang bersangkutan. Pemerintahan Abdulhamid II, tidak mengherankan, menandai titik balik menentukan dalam sikap Ottoman terhadap sistem kapitulasi.

Kapitulasi tidak lagi dianggap hanya sebagai pelanggaran kedaulatan kekaisaran, kapitulasi itu kemudian dilihat sebagai penghalang utama bagi pembangunan (ekonomi) masa depan Kekaisaran Ottoman. Kemakmuran Jerman yang terus meningkat, yang ekonominya dilindungi oleh tarif tinggi, tampaknya menawarkan pendekatan baru kepada Daulauh Utsmaniyah. Mengangkat tarif Ottoman tidak hanya akan memberikan pendapatan yang sangat dibutuhkan tetapi juga bisa merangsang pertumbuhan industri domestik. Baru setelah dua puluh enam tahun negosiasi, para penandatangan kapitulasi menyetujui pada tahun 1907 untuk menaikkan tarif Ottoman dari 4 hingga 7 persen selama peningkatan pendapatan itu datang di bawah penyampaian Utang Utang Utsmaniyah. Kekuatan Barat mendikte bahwa seperempat dari pendapatan tersebut harus digunakan untuk melayani utang Utsmani besar, sementara sisanya akan digunakan untuk membiayai reformasi di Makedonia. Sejauh menyangkut Eropa, Kekaisaran Ottoman memiliki semua contoh dan tujuan menjadi koloni lain untuk diberikan untuk keuntungan (ekonomi) mereka. 


\section{Dampak Kapitulasi Hukum terhadap Peradilan di Seluruh Wilayah Turki Utsmani dan Kesultanan Aceh Darussalam}

Struktur peradilan Aceh dibentuk sama seperti struktur peradilan Turki. Ini dapat dimengerti, karena banyak ahli peradilan datang dari Turki ke Aceh pada abad ke-16. (Ali Hasymi: 1990), abad ke-19. Setelah periode diam yang panjang, mulai dari tahun-tahun pertama bagian kedua abad ke-19, utusan Aceh mengunjungi tiga kali Istanbul. Selama periode ini, mediator utama antara utusan Istanbul dan Aceh adalah penguasa Ottoman di Hijaz dan Yeman gubernur. Pada bagian kedua abad ke-19, tiga kali, -1851, 1868 dan 1872 - Kesultanan Aceh pada masa Sultan Ibrahim Mansur Shah dan Sultan Mahmud Shah mengirim utusan ke İstanbul untuk memperbarui hubungan lama dan mencari perlindungan sebagai negara vasal untuk diselamatkan dari invasi Belanda. Meskipun utusan-utusan itu menyajikan semua rincian kondisi di Aceh kepada penguasa Negara Ottoman, tidak ada yang terjadi untuk menghidupkan kembali hubungan tersebut. Dan upaya ini berakhir dengan kegagalan dan utusan Aceh berbalik dengan tangan kosong. Kita dapat melihat beberapa fakta di balik perkembangan ini. Misalnya, karena keputusan beberapa negarawan yang tidak memberikan respons positif terhadap petisi utusan Aceh dan tekanan dari kalangan internasional, terutama duta besar Belanda di Istanbul, kunjungan-kunjungan ini tidak membawa pada akhir yang sukses. Tetapi ketika kita melihat sejarah dari sekarang, tidak diragukan lagi tampaknya bahwa keputusan salah yang diambil oleh birokrat Ottoman di Istanbul mempersiapkan akhir dari dua negara setelah beberapa dekade. Selama kunjungan Abdurrahman Zahir Efendi ke İstanbul, bertentangan dengan keputusan birokrat Ottoman yang tidak beralasan, seperti yang kita lihat jurnal 'Basiret', beberapa media sangat mementingkan kasus Aceh dan menerbitkan artikel dengan gagasan kuat bahwa Negara Ottoman harus memberikan dukungannya. kepada orang Aceh. Di luar ini, jurnal yang berjudul 'Servet' (Uka Tjandrasasmita: tth.) memberikan tempat beberapa foto dalam kaitannya dengan kehidupan sosial di Aceh untuk menciptakan kepekaan terhadap kasus Aceh di masyarakat Ottoman. Sehubungan dengan Perang Belanda di Aceh pada paruh kedua abad ke-19, jurnal 'Basiret' menerbitkan banyak berita antara tahun 1873 dan 1874. Ada sekitar 75 berita dan kritik tentang acara ini di Basiret.

\section{PENUTUP}

Turki Utsmani berdiri diatas Syari'ah Islam, yang pada mulanya hanya sebuah kesultanan kemudian kekuasaannya berkembang sampai ke pintu gerbang kota Wina (Austria), wilayah Utara Afrika, Arab dan teritorinya sampai ke Aceh Darssalam. Akan tetapi berputar 
haluan justru ketika pada masa kekuatan penguasa Turki Utsmani yang dimulai dari Muhammad al-Fatih dan yang lebih jelas apa yang dilakukan oleh Sulaiman al-Qanuni (1530). Bermula dari perjanjian dagang yang menguntungkan Perancis, dengan tidak diberlakukannya aturan Daulah Utsmaniyah terhadap warga Perancis dan yang mengatasnamakan Perancis di wilayah Turki Utsmani. Keuntungan sepihak, karena Daulah Utsmaniyah tidak mendapatkan perlakukan yang sama ketika warganya berada di Perancis.

Perjanjian Kapitulasi Hukum yang menguntungkan pada masa jaya, karena para pedagang dirangsang untuk melakukan aktifitas dipelabuhan-pelabuhan Turki Utsmani terutama di Istanbul. Penambahan devisa negara secara signifikan, sehingga aktifitas-aktifitas besar dilakukan tanpa ada kegoncangan moneter. Setelah terjadi krisis kepemimpinan, perjanjian kapitulasi hukum ini berbuah menjadi malapetaka. Konsul-konsul asing semakin banyak, perjanjian diperluas dan peradilan-peradilan syari'at mulai kehilangan fungsi karena banyak warga negara Nasrani dan Yahudi yang tidak pernah mengenal negara Perancis, Inggris dan Eropa lainnya telah berlindung dibalik perjanjian Kapitulasi yang mendapatkan hak istimewa dalam keringanan pajak, kebal hukum perdata maupun Pidana. Hal ini berujung kepada sekularisme Hukum Turki Utsmani yang memuat materi-materi Hukum Eropa. Terjadilah Tanzimat yang tidak terkontrol, seharusnya hanya di bidang teknologi dan strategi militer dan ekonomi akan tetapi telah merambah kepada sistim peradilan dan materi hukum. Yang berakhir dengan hilangnya kedaulatan Turki Utsmani.

\section{REFERENSI}

Asy-Syalabi, Ali Muhammad (2003). Bangkit dan Runtuhnya Khilafah 'Utsmaniyah. Pustaka Al-Kautsar

Ali Muhammad Shalabi Daulah Utsmaniyah Awamil an-Nuhudh wa Asbab as-Suqut (Beirut, Dar alFikr, 2006)

Altan, Gokalp, La Turquie en Transition, Paris, 1986.

Abdurrahman Pasha: 'Osmanlı kanunnameleri', Milli Tetebbu 'lerMecmuası, 1 (1913),

Ahmedi: Ahmedi, 'Tevarih-i Muluk-i Al-i Osman', in C.N. Atsız,Osmanl Taribleri (Istanbul, 1949).

A.H. Lyber: The Government of the Ottoman Empire, Harvard UniversityPress, Harvard 1913.

A.L.Srivastava: Akbar the Great: Political History 1542- 1605), ShivalaAgarwala \& Co, Delhi. V. L. 
Anonymous author: ed. (Yas, ar Yucel), Kitab-i Mustetab (Ankara, 1974).

Anonymous chronicle of 1485: Bodleian Library, Oxford, ms. Marsh 313.

See V.L. Menage, Neshri's History of the Ottomans (London, 1964)

Ashikpashazade: Ashikpashazade (ed. Ali), Tevarih-i Al-i Osman

(Istanbul, 1913-14); (trans. R. Kreutel), Vom Hirtenzelt zur HohenPforte (Graz, 1959).

Atai: Ata’i, Hada’iq al-Haqa’iq fi Takmilat al-Shaqa’iq (Istanbul, 1851-2).

Ayn Ali: Ayn Ali Efendi, Kavanin-i Al-i Osman der Hulasa-i Mezamin-i

Defter-i Divan (Istanbul, 1863; repr. Istanbul, 1979).

Antoine Hakyem: Les Provinces Arabes de l'empire Ottoman aux Archives du Ministère des Affaires Etrangères de France (1793- 1918). Les Editions Universitairs du Liban 1988.

'Abdul Wahhāb Khallāf, Al-Sultāt al-Tsalāts fì al-Isläm: Al-Tashrī', al-Qadlā', al-Tanfìdr, Kuwait, Dār al-Qalam, Cet. 2, 1405H/1985M

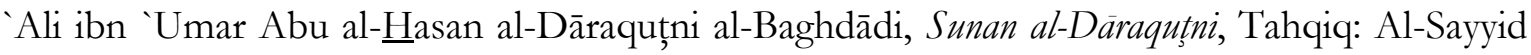
‘Abdullah Hāshim Yamāni al-Madani, Beirut, Dar al-Ma rifah, 1386H/1966

Abu al-Rabī Sulaymān ibn Mūsā al-Kalā’ i al-Andalusi, Al-Iktifä’ bi Mā Tadlammanahu min Maghäri Rasülillah wa al-Tsalätsah al-Khulafä, Tahqiq: Dr. Muhamad Kamāl al-Dīn 'Izz al-Dīn `Ali, Beirut, `Ālam al-Kutub, Cet. 1, 1417H

Abū Dāwud Sulaymān ibn al-Ash`ats al-Sijistāni, Sunan Abì Dāwnd, Beirut, Dār al-Kitāb alArabi

Abu Munhamad `Abd al-Malik Ibn Hishām ibn Ayyūb al-Himyari, Al-Sìrah al-Nabawiyyah, Tahqiq: Țāhā `Abd al-Ra’ūf Sa`ad, Beirut, Dar al-Jīl, 1411H

Ahnmad ibn Hanbal, Musnad Ahmad ibn $\underline{H}$ anbal, Tahqiq: Shu'aib al-Arna'ūț .et.al, Beirut, Mu'assasah al-Risalah, cet. 2, 1420H/1999M

Al-Bayhaqi, Al-Sunan al-Kubro, vol. X, hlm. 252 dalam Software al-Maktabah al-Shāmilah

Al-Māwardi, Al-Ahkām al-Sulțāniyah, dalam Software Al-Maktabah al-Shāmilah

Bernard Lewis: The Arabs in History, Paperback, May 2002.

Bernard Lewis: The Emergence of Modern Turkey, Oxford University press,1968.

Charles Fraze: Catholics and Sultans: The Church and the Ottoman Empire(1453- 1923), 1983.

Bittar,T., Soliman. L’empire magnifique, Paris, Gallimard Découvertes, 1994 
Badri Yatim, Sejarah Peradaban Islam (Jakarta: PT. Raja Grafindo Persada, 1999),

Belge, Murat (1985). Tanzimat'tan Cumhuriyet'e Türkiye Ansiklopedisi, 6 vols. (Istanbul: İletişim) .

Bacque-Grammont, J.L. et Duman, P., Economie et Societes dansl'Empire Ottoman, Paris, 1983.

Barne,s Johen Robert, An Introduction to Religious Foundations inthe Ottoman Empire, Leiden, E.J.Brill, 1986.

Batu, H. et Baque-Grammont, J .L., L 'Empire Ottoman, la Republiquede Turquie et la France, Istanbul, Paris, 1986.

Bazin, Louis, La Vie Intellectuelle et Culturelle dans Empire Ottoman,en Histoire de /'Empire ottoman, Paris, Fayare, 1989.

Bennigsen, A. etCh. Lemercier-Quelquejay, La Presse et le MouvmentNationale chez les Musulmans de Russie Avant 1920, Paris, La Haye,Mouton, 1964.

Berard, Victor, Le sultan, /'Islam et les Puissances, Paris, LibrairieArmand Colin, 1907.

Beylerian, Arthur, Les Grandes Puissances, /'empire Ottoman et lesArmeniens, dans les Archives Francaises 1914-1918, Paris, Sorbonne,1983.

Brice, W.C., An Historical Atlas of Islam, Leydc, 1981.

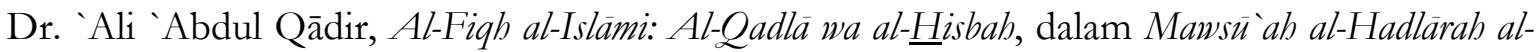
'A rabiyyah al-Islämiyah, Amman \& Beirut, Dār al-Fāris \& Al-Muassasah al-`Arabiyah li al-Dirāsāt wa al-Nashr, Cet. 1, 1995

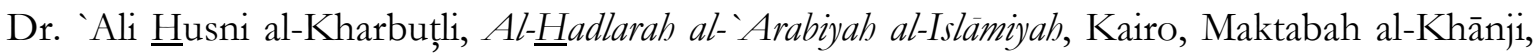
Cet. 2, 1994,

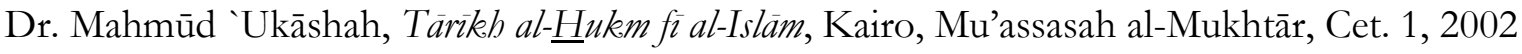

Dr. Muhamad al-Zuhayli, Tärikh al-Qadlā' fì al-Islām, Beirut, Dār al-Fikr al-Mu āşir \& Damaskus, Dār al-Fikr, Cet. 1, 1415/1995

Dr. Naşr Farīd Muhammad Wāşil, Al-Sulțah al-Qadläìiah wa Nidżàm al-Qadlä fì al-Islām, t.t, Maktabah al-Tawfíqiyyah, cet. 2, t.th,

Cahun, L., Introduction a I'bistoire de I'Asie, Paris, 1965.

Celik, L., The Remaking of Istanbul, Portrait of an Ottoman Cityin the Nineteenth Century, Seattle et London, 1986.

Cohen, Moise (Tckin Alp), Turkismus and Panturkismus, Weimar,1915.

Davids, Lumley, Grammaire Turque, Londrcs, 1832.

Davids, R.F., Reform in the Ottoman Empire 1856-1876, NewYouk, 1973. 
(IS) De Guignes, Jean, Histoire Generate des Turcs, des Mongoles et des Huns, Paris, 1756.

Dumontp au, La Periode des Tanzimat (1839-1878), en Histoire de'Empire ottoman, Paris, Fayard, 1989.

Dr. Abdul Karim Zaidan Tarikh al-Qadha fi al-Islam, Beirut, Muasasah ar-Risalah, 1993.

Noer, Deliar (1973). Gerakan Modern Islam di Indonesia 1900-1942. LP3ES. Hindia Baroe, 9 Januari1925

Efendi, Mehmed, Le paradis des infideles, Paris, FM/La decouverte,1981.

Edward Creasy: History of The Ottoman Turks Khayats, Beirut 1968.

Dietrick Gerhard: "Regionalism and corporate Order as a Basic Theme of

European History" in: R. Hatton \& M.S. Anderson (ed): Studies in Diplomatic History, Longman, London, 1970

Findley, C.V., Bureaucratic Reform in the Ottoman Empire, TheSublime Daulauh Utsmaniyah 17891922, Princeton, 1980.

Fisher, H. A.L., Abistory of Europe, Londres, 1955.

Halil Inalick: The Emergence of the Ottomans, in: P.M. Holt. Et al.

Cambridge History of Islam, The Cambridge University Press, Cambridge,1970.

11-H.J. Kissling. et. al. (eds): The Muslim World (III): The Last Great Muslim Empires. E.G.BRILL, Leiden 1969.

Immanuel Wallerstein \& Resat Kasaba: "Corporation into the World Economy: Change in the structure of the Ottoman Empire (1750- 1839)" in: L. Baque Grammant, Contribution à L’histoire Ottomane.

J.C. Hurewitz: The Middle East and North Africa in World Politics: A Documentary Record, Yale University Press, 1975.

J. Modelski: Agrarian and Industrial: Two Models of the International

Muhammad Farid Beik ad-Daulah Iliyah al-Ustmaniyah, Beirut, Muasasah ar-Risalah, 1992

Prof. Muhammad Zuhaili Tarikh al-Qadha fi al-Islam. 